\title{
ANALISIS NERACA SUMBER DAYA AIR DAS KEDUANG
}

\author{
Abdul Ghoffar Ahmad BS1), Rintis Hadiani'2), Solichin') \\ 1) Mahasiswa Program Studi Teknik Sipil Universitas Sebelas Maret Surakarta \\ 2),3) Akademisi Program Studi Teknik Sipil Universitas Sebelas Maret Surakarta \\ Jl. Ir. Sutami 36 A, Surakarta 57126. Email : a.ghoffar.abs@gmail.com
}

\begin{abstract}
Water Availability is an Inportant to pay Attention. If more water is used, the availability will be reduced. Therefore, need a research of water balance, to can maka the good planning, so that water can meet human needs.

The Data used in this research is secondary data in the form of rain-fall data, climatology, population, number of livestock, industrial, fishery, Planting calendar dan area of irigation land. The reseach is using GR2M method to Analysis rainfall-runoff. Components of water needs are adjusted to SNI 6728.1 years 2015 include the water need for domestic, city, livestock, fishery, irrigation and river maintenance. Rainfall prediction is calculated using the SARIMA Method with Minitab 18 Aplication. Evapotranspiration Analysis is calculated based on RSNI-T-01 years 2004. Water balance maps are made with ArcGIS 10.2.1 Aplications.

The results of the study show that the water balance in 2017 in control point 1 has a biggest surplus of 4,161 x $10^{6} \mathrm{~m}^{3} / \mathrm{mouth}^{\text {in }}$ Februari. While the biggest deficit occurred of 6,926 x $10^{6} \mathrm{~m}^{3} /$ mouth in November. in control point 2, the biggest deficit occurred of 239,862 x $10^{6} \mathrm{~m}^{3} /$ mouth in November. The water balance prediction in 2018, in control point 1 has a biggest surplus of $5,838 \times 10^{6} \mathrm{~m}^{3} /$ mouth in Februari. While the biggest deficit occurred of 6,157 x $10^{6} \mathrm{~m}^{3} /$ mouth in October. in control point 2, the biggest surplus occurred of 7,444 x $10^{6} \mathrm{~m}^{3} /$ mouth in February. While the biggest deficit occurred of $234,838 \times 10^{6}$ $m^{3} /$ mouth in November.
\end{abstract}

Keywords : Keduang watershed, GR2M, predictions, Water balance

\begin{abstract}
Abstrak
Ketersediaan air menjadi hal yang penting untuk diperharikan. Semakin banyak air digunakan, maka ketersediaannya akan semakin berkurang. Oleh karena itu perlu diakukan penelitian mengenai neraca Air, agar nantinya bisa dibuat perencanaan yang baik, sehingga air masih dapat mencukupi kebutuhan masyarakat.

Data yang dibutuhkan dalam penelitian ini menggunakan data sekunder berupa data curah hujan, data klimatologi, jumlah penduduk, jumlah ternak, data industri, data perikanan, kalender tanam, dan luas lahan irigasi. Penelitian ini menggunakan metode GR2M sebagai metode untuk menganalisis Hujan-Debit. Komponen kebutuhan Air disesuaikan dengan SNI 6728.1 tahun 2015 meliputi kebutuhan Rumah tangga, Perkotaan, Industri, Kebutuhan Peternakan, perikanan, Irigasi dan kebutuhan Air untuk pemeliharaan sungai. prediksi curah hujan dihitung menggunakan metode SARIMA dengan bantuan Aplikasi Minitab 18. Analisis evapotranspirasi disesuaikan dengan RSNI -T-01 tahun 2004. Peta Neraca sumber daya air dibuat dengan aplikasi ArcGIS 10.2.1.

Neraca Air pada tahun 2017 Pada sub DAS titik Kontrol 1 terjadi surplus terbesar terdapat pada Bulan Februari sebesar 4,161 x $10^{6} \mathrm{~m}^{3}$ /bulan. Sedangkan defisit terbesar terjadi pada bulan Nopember dengan devisit sebesar 6,926 × $10^{6} \mathrm{~m}^{3} /$ bulan. Pada sub DAS titik Kontrol 2 terjadi defisit terbesar terjadi pada bulan Nopermber dengan defisit sebesar 239,862 x $10^{6} \mathrm{~m}^{3}$ /bulan. Prediksi Neraca Air pada Tahun 2018, Pada sub DAS titik Kontrol 1 terjadi Surplus terbesar terdapat pada Bulan Februari sebesar 5,838 x 106 m³/bulan. Sedangkan defisit terbesar terjadi pada bulan Oktober dengan defisit sebesar 6,157 x $10^{6} \mathrm{~m}^{3} /$ bulan. Pada sub DAS titik Kontrol 2 terjadi surplus Air terbesar pada bulan Februari sebesar 7,444 x $10^{6} \mathrm{~m}^{3} /$ bulan. Sedangkan Defisit terbesar terjadi pada bulan Nopermber dengan defisit sebesar 234,838 x $10^{6} \mathrm{~m}^{3} /$ bulan.
\end{abstract}

Kata Kunci : DAS Keduang, GR2M, prediksi, Neraca Air.

\section{PENDAHULUAN}

Seiring dengan bertambahnya jumlah penduduk dan berkembangnya suatu wilayah, mengakibatkan kebutuhan air semakin bertambah banyak. Setiap aktivitas dan kebutuhan pangan penduduk sangat erat kaitannya dengan kebutuhan akan air. Hal ini tidak mungkin dihindari, sehingga perlu adanya perencanaan dan prediksi yang matang dalam pengelolaan air dan penggunaannya di tengah-tengah masyarakat. 
Masalah yang sering terjadi adalah ketidakseimbangan antara penggunaan air dan ketersediaan air di dalam suatu wilayah. Untuk bisa menyelesaikan permasalahan tersebut, diperlukan upaya penelitian guna mengkaji komponen-komponen kebutuhan air dan efisiensi penggunaannya. Dengan adanya penelitian tersebut, dapat dibuat perencanaan dan pengaturan yang paling efektif agar diperoleh solusi yang bisa menyelesaikan masalah tersebut.

Diantara komponen-komponen kebutuhan air berdasarkan SNI 6728.1 tahun 2015 yaitu jumlah penduduk, jumlah ternak dan jenis ternak, perikanan dan perindustrian dan kebutuhan air untuk pemeliharaan sungai. Selain itu, Irigasi juga menjadi salah satu komponen terbesar dalam komponen kebutuhan air.

Tujuan dari penelitian ini adalah untuk Mengetahui neraca sumber daya air di DAS Keduang tahun 2017, prediksi neraca sumber daya air di DAS Keduang tahun 2018 dan mengetahui peta neraca sumber daya air di DAS Keduang pada tahun 2017 dan 2018.

\section{TINJAUAN PUSTAKA}

Neraca sumber daya air adalah informasi tentang imbangan potensi, ketersediaan, dan penggunaan atau kebutuhan sumber daya air pada kurun waktu tertentu (SNI 6728.1:2015).

DAS keduang merupakan salah satu DAS yang memberi suplay air menuju waduk wonogiri. DAS keduang memiliki pengarus besar terhadap besar kecilnya volume di waduk wonogiri. Hal ini disebabkan karena Sebagian wilayah DAS keduang terletak dilereng gunung Lawu, sehingga kemungkinan suplay air paling besar menuju waduk wonogiri berasal dari DAS Keduang ini.

Ada beberapa penelitian yang sudah menggunakan metode GR2M, diantaranya penelitian tentang simulasi hujandebit di daerah aliran sungai bolon yang dilakukan oleh Yosephina (2015) dan penelitian tentang tranformasi hujan-debit berdasarkan analisis tank model dan GR2M di DAS dengkleng oleh Destiana (2016).

Dalam penyajian hasil penelitian, ada banyak macam penyajian yang bisa dilakukan, ada yang berupa tabel, grafik, dan gambar. penyajian data berbasis GIS adalah salah satu model penyajian hasil penelitian yang berupa gambar. Dengan menggunakan basis GIS, data hasil penelitian akan lebih mudah difahami pembaca.

Salah satu aplikasi GIS yang terkenal dan banyak digunakan dalam suatu penelitian adalah AroGIS. ArcGIS adalah salah satu aplikasi untuk pemetan suatu wilayah. Pada penelitian ini, ArcGIS yang dipakai adalah ArcGIS Versi 10.2 .1

\section{LANDASAN TEORI}

\section{Karakteristrik Hujan}

Data hujan yang diperoleh, kemudian di uji konsistensinya dengan menggunakan metode kurva massa ganda, setelah dinyatakan konsisten, data kemudian di olah untuk mencari hujan wilayahnya dengan menggunakan metode poligon thiessen. Hujan wilayah Daerah Aliran Sungai (DAS) dicari dengan metode poligon thiessen seperti dalam persamaan (1) :

$P_{\text {rata-rata }}=\frac{P_{1} A_{1}+P_{2} A_{2}+\cdots+P_{n} A_{n}}{A_{1}+A_{2+\cdots+A_{n}}}$

Dengan :

$\mathrm{P} \quad=$ Tebal Hujan $(\mathrm{mm})$,

A = Luas Wilayah poligon theissen $\left(\mathrm{km}^{2}\right)$,

n = Jumlah Stasiun hujan.

\section{Evapotranspirasi tanaman Acuan (ETo)}

Evapotranspirasi tanaman acuan ( $\left.\mathrm{ET}_{0}\right)$ adalah evapotranspirasi yang tejadi pada tanaman acuan yaitu tanaman yang tumbuh pada suatu lahan dengan ketinggian tanaman $12 \mathrm{~cm}$ dari permukaan tanah dan kebutuhan airnya tercukupi dengan baik (RSNI-T-01-2004). Rumus yang digunakan adalah rumus Penman-Monteith, rumus Penman-Monteith dapat dilihat pada persamaan (2) :

$\mathrm{ET}_{0}=\frac{0,408 \Delta R n+\gamma \frac{900}{T+273} U_{2}\left(e_{S}-e_{a}\right)}{\Delta+\gamma\left(1+0,34 U_{2}\right)}$

Dengan :

ET $_{\mathrm{o}}=$ Evapotranspirasi tanaman acuan $(\mathrm{mm} / \mathrm{hari})$, 


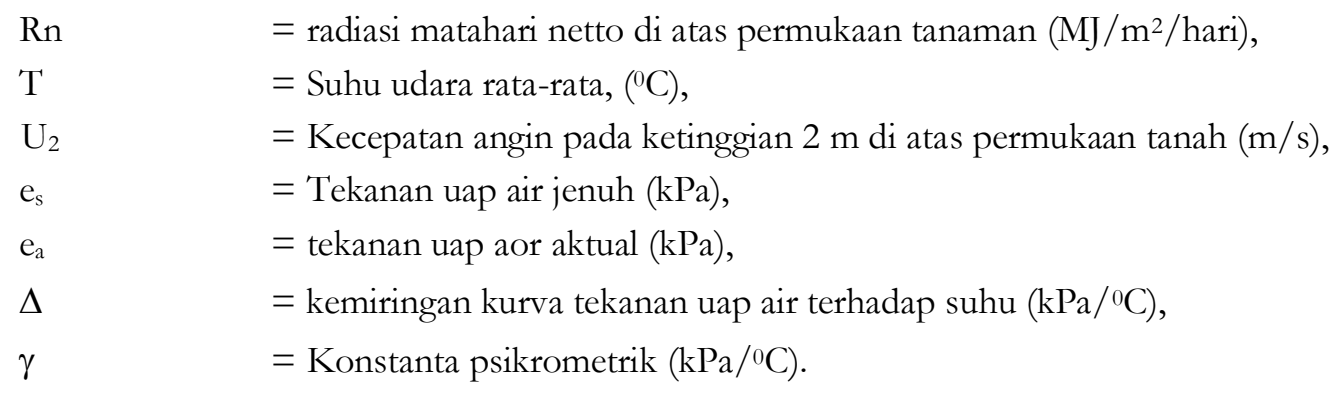

\section{Ketersediaan Air}

Ketersediaan air dihitung berdasarkan perhitungan hujan-Debit GR2M yang dapat dilihat pada persamaan (3) Persamaan (11) :

(1) $\mathrm{S}_{1}=\frac{S_{0}+X_{i} \varphi}{1+\varphi \frac{S_{0}}{X_{1}}}$ dengan $\varphi=\tanh \left(\frac{P}{x_{1}}\right)$

(2) $\quad \mathrm{P}_{1}=\mathrm{P}+\mathrm{S}_{0}-\mathrm{S}_{1}$

(3) $\mathrm{S}_{2}=\frac{S_{1}(1+\psi)}{1+\Psi\left(1-\frac{S_{1}}{X_{1}}\right)} \operatorname{dengan} \Psi=\tanh \left(\frac{E t p}{X_{1}}\right)$.

(4) $\quad \mathrm{Sa}=\frac{S_{2}}{\left(1+\left(\frac{S_{2}}{X_{1}}\right)^{3}\right)^{1 / 3}}$

(5) $\quad \mathrm{P}_{2}=\mathrm{S}_{2}-\mathrm{Sa}$

(6) $\quad \mathrm{P}_{3}=\mathrm{P}_{1}+\mathrm{P}_{2}$

(7) $\quad \mathrm{R}_{1}=\mathrm{R}+\mathrm{P}_{3}$

(8) $\quad \mathrm{R}_{2}=\mathrm{X}_{2} \times \mathrm{R}_{1}$

(9) $\mathrm{Q}=\frac{R_{2}^{2}}{R_{2}+60}$

Dengan :

$\mathrm{S}_{1} \quad=$ Kelengasan tanah akibat Presipitasi ( $\mathrm{mm} /$ Bulan),

$\mathrm{S}_{0} \quad=$ Kelengasan Awal tanah (mm/Bulan). Nilai kelengasan awal tanah untuk bulan pertama perhitungan maksimal sebesar $\mathrm{X}_{1}$, sedangkan nilai kelengasan awal tanuh untuk bulan lain sebesar $\mathrm{S}$ pada bulan sebelumnya ( $\mathrm{mm} /$ bulan),

$\mathrm{P} \quad=$ Curah Hujan Bulanan $(\mathrm{mm})$,

$\mathrm{X}_{1} \quad=$ Kelengasan maksimum tanah $(\mathrm{mm} /$ bulan $)$,

P1 = Aliran Permukaan ( $\mathrm{mm} /$ bulan),

S2 = Kelengasan tanah akibat presipitasi dan evapotranspirasi ( $\mathrm{mm} /$ bulan),

ETP = Evapotranspirasi ( $\mathrm{mm} /$ bulan),

$\mathrm{Sa} \quad=$ Kelengasan tanah akibat infiltrasi kelapisan tanah $(\mathrm{mm} / \mathrm{bulan})$,

$\mathrm{P}_{2} \quad=$ Kedalaman hujan akibat pengurangan $\mathrm{S}_{2}-\mathrm{S}(\mathrm{mm} /$ bulan $)$,

$\mathrm{P}_{3} \quad=$ Kedalaman hujan total $\left(\mathrm{P}_{1}+\mathrm{P}_{2}\right)(\mathrm{mm} /$ bulan $)$,

$\mathrm{R}=$ Nilai Routing (mm/bulan). Nilai Routing untuk bulan pertama perhitungan maksimal sebesar $60 \mathrm{~mm} /$ bulan. Sedangkan nilai routing bulan lain sebesar $\mathrm{R}$ pada bulan sebelumnya,

Q $\quad=$ Debit Runoff (mm/bulan).

Kemudian dicari debit andalan Q80 dengan metode probabilitas weibull. Q80 inilah ketersediaan neraca sumber saya Airnya.

\section{Kebutuhan Air}


Kebutuhan air yang digunakan adalah kebutuhan Air untuk RKI (Rumah tangga, Perkotaan, dan Industri), Kebutuhan Air Peternakan, Kebutuhan Air Perikanan, Kebutuhan Air Irigasi dan Kebutuhan Air untuk pemeliharaan sungai.

a. Kebutuhan Air RKI

Kebutuhan air rumah tangga dihitung berdasarkan jumlah penduduknya. Sedangkan kebutuhan air perkotaan dihitung sebesar 20\% dari kebutuhan air rumah tangga, dan kebutuhan Air Industri dihitung berdasarkan banyaknya jumlah karyawan. Besarnya kebutuhan air untuk penduduk adalah 60 liter/orang/hari.

b. Kebutuhan Air Peternakan

Hewan ternak yang masuk dalam penelitian ini adalah kuda,sapi, kerbau dengan kebutuhan air sebesar 40 liter/ekor/hari. Kambing dengan kebutuhan air sebesar 5 liter/ekor/hari, babi dengan kebutuhan air sebesar 6 liter/ekor/hari, dan unggas dengan kebutuhan air sebesar 0,6 liter/ekor/hari.

c. Kebutuhan air Perikanan

Kebutuhan air perikanan dihitung berdasarkan luasan kolam dan tambak ikannya.

d. Kebutuhan air Irigasi

Kebutuhan air irigasi dihitung sesuai rumus kebutuhan irigasi penman monteith

\section{Neraca sumber daya air}

Berdasarkan SNI 6728.1-2015, neraca sumber daya Air tahunan dibagi menjadi 5 klasifikasi dengan warna yang berbeda-beda. Klasifikasi tersebut dapat dilihat pada Tabel 1

Tabel 1 Simbol Warna neraca Air, SNI 6728.1 (2015)

\begin{tabular}{|c|c|c|c|}
\hline No & Klasifikasi & Saldo $=$ Potensi - Penggunaan $\left(10^{6} \mathrm{~m}^{3} /\right.$ tahun $)$ & $\begin{array}{l}\text { Simbol } \\
\text { Warna }\end{array}$ \\
\hline 1 & $\mathrm{I}$ & $>1.500$ & Biru tua \\
\hline 2 & II & $1.000-1500$ & Biru muda \\
\hline 3 & III & $500-1000$ & Hijau \\
\hline 4 & IV & $100-500$ & Kuning \\
\hline 5 & $\mathrm{~V}$ & $<0$ & merah \\
\hline
\end{tabular}

Sedangkan, untuk indeks pemakaian Air (IPA) diklasifikasikan menjadi 4 klasifikasi dengan simbol warna yang berbeda-beda. Penjelasan lengkapnya dapat dilihat pada Tabel 2

Tabel 2 Simbol Warna Indeks Pemakaian Air (IPA), SNI 6728.1 (2015)

\begin{tabular}{lccc}
\hline No & Klasifikasi & Indeks & $\begin{array}{c}\text { Simbol } \\
\text { Warna }\end{array}$ \\
\hline 1 & I & $>0,4$ & Merah \\
\hline 2 & II & $0,2-0,4$ & Kuning \\
\hline 3 & III & $0,1-0,2$ & Hijau \\
\hline 4 & IV & $<0,1$ & Biru \\
\hline
\end{tabular}

\section{METODE PENELITIAN}

\section{Pengolahan Data Hujan}

1. Data hujan di tiga stasiun hujan DAS Keduang yang telah diperoleh diuji kepanggahannya dengan metode kurva massa ganda.

2. Data hujan yang telah panggah kemudian di ubah menjadi hujan wilayah dengan menggunakan metode Poligon Thiessen.

3. Data hujan wilayah kemudian digunakan untuk menghitung prediksi hujan wilayah tahun 2018 dengan menggunakan metode SARIMA dengan bantuan aplikasi minitab 18. 


\section{Perhitungan Evapotranspirasi tanaman Acuan}

Data klimatologi yang telah diperoleh kemudian digunakan untuk mencari nilai evapotranspirasi tanaman acuan dengan menggunakan metode penman monteith. Dalam penelitian ini, evapotranspirasi potensial dihitung berdasarkan acuan RSNI T - 01 Tahun 2004. 


\section{Perhitungan Simulasi Hujan-debit GR2M}

Dari hujan wilayah yang telah diperoleh, kemudian dicari debit yang dihasilkan dengan metode GR2M (Global rainfaa-runoff model)

\section{Perhitungan Debit Andalan}

Setelah besarnya debit diperoleh, kemudian dicari nilai debit andalan 95\% dan $80 \%$ dengan metode kurva durasi debit dengan perhitungan menggunakan rumus Weibull.

\section{Perhitungan kebutuhan air}

Kebutuhan air yang dicari dalam penelitian ini adalah kebutuhan air irigasi, kebutuhan air RKI (rumahtangga, perkotaan dan industri), kebutuhan air peternakan, kebutuhan air perikanan, dan kebutuhan air pemeliharaan sungai. Rumus-rumus yang digunakan disesuaikan dengan SNI 6728.1-2015.

\section{Perhitungan Neraca Sumber Data Air}

Neraca air yang dicari dalam penelitian ini adalah besarnya ketersediaan air dan besarnya kebutuhan air untuk irigasi, dan non irigasi, sesuai dengan SNI 6728.1 tahun 2015. Neraca sumber daya air yang dihitung adalah Neraca sumber daya air tahun 2017 dan prediksi neraca sumber daya air tahun 2018.

\section{HASIL DAN PEMBAHASAN}

\section{Analisis Ketersediaan Air}

Variabel yang digunakan dalam pergitungan GR2M adalah Data Evapotranspirasi bulanan dan curah hujan wilayah bulanan. Dengan memasukkan data-data tersebut dalam persamaan, diperoleh debit GR2M yang dapat dilihat pada tabel 3

Tabel 3. Rekapitulasi Debit GR2M

\begin{tabular}{rrrrrrrrrrrrr}
\hline \multirow{2}{*}{ Tahun } & \multicolumn{1}{c}{ Debit GR2M $\left(\mathrm{m}^{3} / \mathrm{dtk}\right)$} \\
\cline { 2 - 14 } & Jan & Feb & \multicolumn{1}{c}{ Mar } & \multicolumn{1}{c}{ Apr } & Mei & Jun & Jul & Ags & Sep & Okt & Nop & \multicolumn{1}{c}{ Des } \\
\hline 2008 & 7,060 & 11,563 & 15,240 & 8,633 & 1,419 & 0,375 & 0,058 & 0,015 & 0,004 & 0,963 & 16,030 & 5,918 \\
\hline 2009 & 12,783 & 15,516 & 4,046 & 0,610 & 4,186 & 2,260 & 0,333 & 0,071 & 0,023 & 0,270 & 0,340 & 5,588 \\
\hline 2010 & 12,416 & 17,885 & 20,672 & 12,974 & 20,516 & 6,116 & 1,928 & 1,946 & 8,458 & 17,521 & 2,197 & 25,492 \\
\hline 2011 & 25,723 & 18,059 & 21,408 & 16,195 & 9,701 & 2,240 & 0,232 & 0,054 & 0,014 & 0,062 & 16,381 & 21,818 \\
\hline 2012 & 34,527 & 25,314 & 13,797 & 23,060 & 2,231 & 2,096 & 0,239 & 0,058 & 0,015 & 0,056 & 9,527 & 22,569 \\
\hline 2013 & 37,789 & 19,406 & 7,477 & 24,764 & 6,382 & 7,535 & 1,012 & 0,382 & 0,321 & 1,549 & 6,861 & 16,508 \\
\hline 2014 & 18,104 & 3,548 & 4,247 & 4,889 & 0,607 & 1,399 & 0,222 & 0,054 & 0,046 & 0,071 & 4,102 & 16,503 \\
\hline 2015 & 37,351 & 21,126 & 9,194 & 27,330 & 7,166 & 8,259 & 1,118 & 0,195 & 0,045 & 0,820 & 6,226 & 16,679 \\
\hline 2016 & 7,514 & 15,099 & 9,921 & 5,124 & 3,599 & 5,252 & 1,649 & 0,701 & 4,343 & 7,706 & 17,377 & 3,907 \\
\hline 2017 & 10,219 & 23,944 & 17,635 & 21,086 & 4,511 & 2,097 & 0,276 & 0,045 & 0,129 & 0,232 & 8,536 & 7,413 \\
\hline 2018 & 14,875 & 26,591 & 22,178 & 27,942 & 10,493 & 7,376 & 1,719 & 0,684 & 0,642 & 1,441 & 10,306 & 17,503 \\
\hline
\end{tabular}

Setelah diperoleh debit dari analisis Hujan-Debit GR2M, kemudian di cari debit andalan Q80 dengan metode probabilitas waibull.

\section{Analisis Kebutuhan Air}

Kebutuhan air yang dihitung adalah kebutuhan air untuk RKI, Peternakan, Perikanan, Irigasi dan pemeliharaan Sungai. Karena data untuk perikanan tidak ada, maka, kebutuhan air yang digunakan dianggap 0.

\section{Neraca Sumber Daya Air}

Neraca sumber daya air selengkapnya dapat dilihat pada Tabel 4 - Tabel 7 
Tabel 4. Neraca Sumber Daya Air Sub DAS Titik Kontrol 1 tahun 2017

\begin{tabular}{|c|c|c|c|c|c|c|c|c|c|c|c|c|}
\hline \multirow{2}{*}{ Kebutuhan air } & \multicolumn{12}{|c|}{ Kebutuhan Air Irigasi ( $\times 10^{6} \mathrm{~m}^{3} /$ bulan $)$} \\
\hline & Jan & Feb & Mar & Apr & Mei & Jun & Jul & Ags & Sep & Okt & Nov & Des \\
\hline Kebutuhan Air RKI & 0,167 & 0,151 & 0,167 & 0,161 & 0,167 & 0,161 & 0,167 & 0,167 & 0,161 & 0,167 & 0,161 & 0,167 \\
\hline $\begin{array}{l}\text { Kebutuhan Air } \\
\text { Peternakan }\end{array}$ & 0,022 & 0,020 & 0,022 & 0,021 & 0,022 & 0,021 & 0,022 & 0,022 & 0,021 & 0,022 & 0,021 & 0,022 \\
\hline Kebutuhan Air Irigasi & 0,388 & 1,429 & 3,530 & 2,315 & 2,878 & 0,766 & 0,091 & 0,000 & 0,000 & 6,115 & 8,174 & 2,263 \\
\hline Kebutuhan Air Perikanan & 0,000 & 0,000 & 0,000 & 0,000 & 0,000 & 0,000 & 0,000 & 0,000 & 0,000 & 0,000 & 0,000 & 0,000 \\
\hline $\begin{array}{l}\text { Kebutuhan air } \\
\text { pemeliharaan sungai }\end{array}$ & 2,400 & 1,089 & 1,375 & 0,201 & 0,206 & 0,123 & 0,020 & 0,005 & 0,001 & 0,019 & 0,112 & 1,328 \\
\hline $\begin{array}{l}\text { Kebutuhan Air di sub } \\
\text { DAS TK } 1\end{array}$ & 2,976 & 2,689 & 5,094 & 2,698 & 3,273 & 1,072 & 0,299 & 0,194 & 0,184 & 6,323 & 8,468 & 3,779 \\
\hline $\begin{array}{l}\text { Ketersediaan Air diDAS } \\
\text { TK } 1\end{array}$ & 4,979 & 6,850 & 3,024 & 2,952 & 0,977 & 0,920 & 0,139 & 0,029 & 0,009 & 0,040 & 1,542 & 3,494 \\
\hline Neraca Air & 2,002 & 4,161 & $-2,069$ & 0,254 & $-2,296$ & $-0,152$ & $-0,161$ & $-0,165$ & $-0,175$ & $-6,283$ & $-6,926$ & $-0,285$ \\
\hline Indeks Pemakaian Air & 0,60 & 0,39 & 1,68 & 0,91 & 3,35 & 1,17 & 2,16 & 6,69 & 21,36 & 160,06 & 5,49 & 1,08 \\
\hline simbol warna & Merah & Kuning & Merah & Merah & Merah & Merah & Merah & Merah & Merah & Merah & Merah & Merah \\
\hline
\end{tabular}

Tebel 5. Neraca Sumber Daya Air sub DAS Titik Kontrol 2 Tahun 2017

\begin{tabular}{|c|c|c|c|c|c|c|c|c|c|c|c|c|}
\hline \multirow{2}{*}{ Kebutuhan air } & \multicolumn{12}{|c|}{ Kebutuhan Air Irigasi ( $\times 10^{6} \mathrm{~m}^{3} /$ bulan) } \\
\hline & Jan & Feb & Mar & Apr & Mei & Jun & Jul & Ags & Sep & Okt & Nov & Des \\
\hline Kebutuhan Air RKI & 0,441 & 0,398 & 0,441 & 0,427 & 0,441 & 0,427 & 0,441 & 0,441 & 0,427 & 0,441 & 0,425 & 0,439 \\
\hline $\begin{array}{l}\text { Kebutuhan Air } \\
\text { Peternakan }\end{array}$ & 0,047 & 0,043 & 0,047 & 0,046 & 0,047 & 0,046 & 0,047 & 0,047 & 0,046 & 0,047 & 0,046 & 0,047 \\
\hline Kebutuhan Air Irigasi & 11,594 & 25,543 & 66,609 & 41,511 & 51,451 & 19,458 & 6,709 & 0,000 & 0,000 & 182,663 & 244,158 & 67,585 \\
\hline $\begin{array}{l}\text { Kebutuhan Air } \\
\text { Perikanan }\end{array}$ & 0,000 & 0,000 & 0,000 & 0,000 & 0,000 & 0,000 & 0,000 & 0,000 & 0,000 & 0,000 & 0,000 & 0,000 \\
\hline $\begin{array}{l}\text { Kebutuhan air } \\
\text { pemeliharaan sungai }\end{array}$ & 8,000 & 3,631 & 4,585 & 0,669 & 0,688 & 0,412 & 0,066 & 0,017 & 0,005 & 0,064 & 0,373 & 4,428 \\
\hline $\begin{array}{l}\text { Kebutuhan Air di sub } \\
\text { DAS TK } 2\end{array}$ & 20,082 & 29,616 & 71,682 & 42,652 & 52,627 & 20,342 & 7,263 & 0,506 & 0,477 & 183,216 & 245,002 & 72,499 \\
\hline Sisa Debit dari TK1 & 2,002 & 4,161 & 0,000 & 0,254 & 0,000 & 0,000 & 0,000 & 0,000 & 0,000 & 0,000 & 0,000 & 0,000 \\
\hline $\begin{array}{l}\text { Ketersediaan Air } \\
\text { diDAS TK } 2\end{array}$ & 18,599 & 26,996 & 10,082 & 10,096 & 3,258 & 3,067 & 0,462 & 0,096 & 0,029 & 0,132 & 5,140 & 11,649 \\
\hline Neraca Air & $-1,483$ & $-2,620$ & $-61,600$ & $-32,556$ & $-49,369$ & $-17,275$ & $-6,801$ & $-0,409$ & $-0,449$ & $-183,084$ & $-239,862$ & $-60,850$ \\
\hline Indeks Pemakaian Air & 1,080 & 1,097 & 7,110 & 4,225 & 16,153 & 6,633 & 15,727 & 5,242 & 16,636 & 1391,281 & 47,667 & 6,223 \\
\hline simbol warna & Merah & Merah & Merah & Merah & Merah & Merah & Merah & Merah & Merah & Merah & Merah & Merah \\
\hline
\end{tabular}

Tabel 6. Neraca Sumber Daya Air sub DAS Titik Kontrol 1 tahun 2018

\begin{tabular}{|c|c|c|c|c|c|c|c|c|c|c|c|c|}
\hline \multirow{2}{*}{ Kebutuhan air } & \multicolumn{12}{|c|}{ Kebutuhan Air Irigasi ( $\times 10^{6} \mathrm{~m}^{3} /$ bulan) } \\
\hline & Jan & Feb & Mar & Apr & Mei & Jun & Jul & Ags & Sep & Okt & Nov & Des \\
\hline Kebutuhan Air RKI & 0,163 & 0,147 & 0,163 & 0,157 & 0,163 & 0,157 & 0,163 & 0,163 & 0,157 & 0,163 & 0,157 & 0,163 \\
\hline Kebutuhan Air Peternakan & 0,022 & 0,020 & 0,022 & 0,021 & 0,022 & 0,021 & 0,022 & 0,022 & 0,021 & 0,022 & 0,021 & 0,022 \\
\hline Kebutuhan Air Irigasi & 0,327 & 1,236 & 3,327 & 2,118 & 2,875 & 0,662 & 0,091 & 0,000 & 0,000 & 5,996 & 8,106 & 2,095 \\
\hline Kebutuhan Air Perikanan & 0,000 & 0,000 & 0,000 & 0,000 & 0,000 & 0,000 & 0,000 & 0,000 & 0,000 & 0,000 & 0,000 & 0,000 \\
\hline $\begin{array}{l}\text { Kebutuhan air pemeliharaan } \\
\text { sungai }\end{array}$ & 2,618 & 1,188 & 1,500 & 0,219 & 0,225 & 0,135 & 0,022 & 0,006 & 0,002 & 0,021 & 0,122 & 1,449 \\
\hline $\begin{array}{l}\text { Kebutuhan Air di sub DAS } \\
\text { TK } 1\end{array}$ & 3,130 & 2,591 & 5,012 & 2,515 & 3,284 & 0,975 & 0,297 & 0,190 & 0,180 & 6,201 & 8,407 & 3,728 \\
\hline $\begin{array}{l}\text { Ketersediaan Air diDAS } \\
\text { TK } 1\end{array}$ & 6,316 & 8,429 & 4,621 & 3,065 & 1,379 & 1,254 & 0,144 & 0,033 & 0,009 & 0,044 & 2,453 & 3,658 \\
\hline Neraca Air & 3,186 & 5,838 & $-0,391$ & 0,549 & $-1,906$ & 0,279 & $-0,153$ & $-0,157$ & $-0,171$ & $-6,157$ & $-5,953$ & $-0,070$ \\
\hline Indeks Pemakaian Air & 0,496 & 0,307 & 1,085 & 0,821 & 2,382 & 0,778 & 2,068 & 5,731 & 20,083 & 140,954 & 3,427 & 1,019 \\
\hline
\end{tabular}




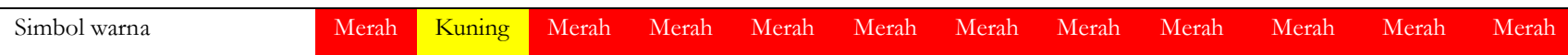

Tabel 7. Neraca Sumber Daya Air Sub DAS Titik Kontrol 2 Tahun 2018

\begin{tabular}{|c|c|c|c|c|c|c|c|c|c|c|c|c|}
\hline \multirow{2}{*}{ Kebutuhan air } & \multicolumn{12}{|c|}{ Kebutuhan Air Irigasi (x $10^{6} \mathrm{~m}^{3} /$ bulan $)$} \\
\hline & Jan & Feb & Mar & Apr & Mei & Jun & Jul & Ags & Sep & Okt & Nov & Des \\
\hline $\begin{array}{l}\text { Kebutuhan Air } \\
\text { RKI }\end{array}$ & 0,438 & 0,395 & 0,438 & 0,424 & 0,438 & 0,424 & 0,438 & 0,438 & 0,424 & 0,438 & 0,422 & 0,436 \\
\hline $\begin{array}{l}\text { Kebutuhan Air } \\
\text { Peternakan }\end{array}$ & 0,047 & 0,043 & 0,047 & 0,046 & 0,047 & 0,046 & 0,047 & 0,047 & 0,046 & 0,047 & 0,046 & 0,047 \\
\hline $\begin{array}{l}\text { Kebutuhan Air } \\
\text { Irigasi }\end{array}$ & 9,779 & 22,094 & 63,779 & 38,752 & 51,385 & 16,819 & 6,709 & 0,000 & 0,000 & 179,105 & 242,142 & 62,571 \\
\hline $\begin{array}{l}\text { Kebutuhan Air } \\
\text { Perikanan }\end{array}$ & 0,000 & 0,000 & 0,000 & 0,000 & 0,000 & 0,000 & 0,000 & 0,000 & 0,000 & 0,000 & 0,000 & 0,000 \\
\hline $\begin{array}{l}\text { Kebutuhan air } \\
\text { pemeliharaan } \\
\text { sungai }\end{array}$ & 8,727 & 3,961 & 5,002 & 0,730 & 0,751 & 0,449 & 0,072 & 0,019 & 0,005 & 0,070 & 0,407 & 4,830 \\
\hline $\begin{array}{l}\text { Kebutuhan Air di } \\
\text { sub DAS TK } 2\end{array}$ & 18,991 & 26,494 & 69,266 & 39,951 & 52,621 & 17,737 & 7,265 & 0,504 & 0,475 & 179,660 & 243,017 & 67,884 \\
\hline $\begin{array}{l}\text { Sisa Debit dari } \\
\text { TK1 }\end{array}$ & 3,186 & 5,838 & 0,000 & 0,549 & 0,000 & 0,279 & 0,000 & 0,000 & 0,000 & 0,000 & 0,000 & 0,000 \\
\hline $\begin{array}{l}\text { Ketersediaan Air } \\
\text { diDAS TK } 2\end{array}$ & 24,241 & 33,938 & 15,405 & 10,766 & 4,596 & 4,458 & 0,478 & 0,111 & 0,030 & 0,147 & 8,178 & 12,194 \\
\hline Neraca Air & 5,250 & 7,444 & $-53,861$ & $-29,185$ & $-48,025$ & $-13,279$ & $-6,787$ & $-0,393$ & $-0,445$ & $-179,514$ & $-234,838$ & $-55,690$ \\
\hline $\begin{array}{l}\text { Indeks Pemakaian } \\
\text { Air }\end{array}$ & 0,783 & 0,781 & 4,496 & 3,711 & 11,450 & 3,979 & 15,184 & 4,558 & 15,884 & 1224,999 & 29,715 & 5,567 \\
\hline simbol warna & Merah & Merah & Merah & Merah & Merah & Merah & Merah & Merah & Merah & Merah & Merah & Merah \\
\hline
\end{tabular}

Berikut adalah peta Neraca sumber Daya Air DAS Keduang tahun 2017 dan 2018

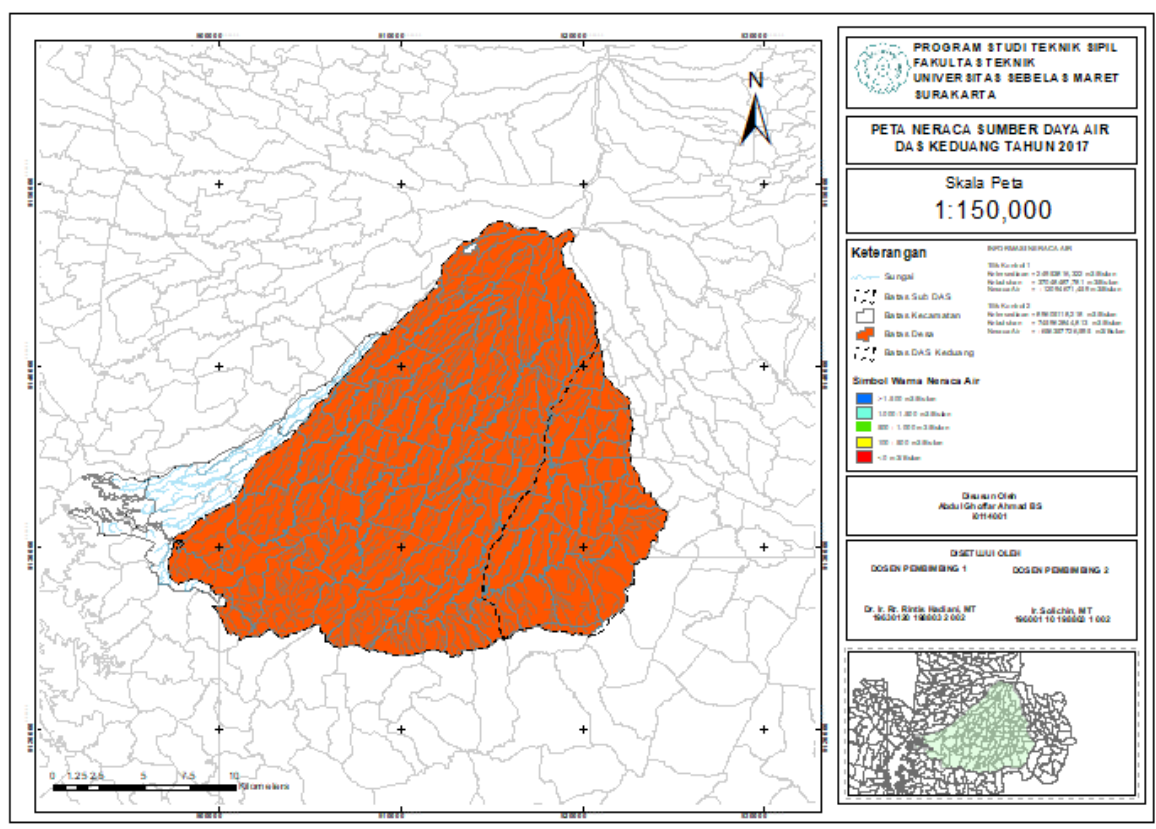

Gambar 1. Peta Neraca Sumber Daya Air Tahun 2017 


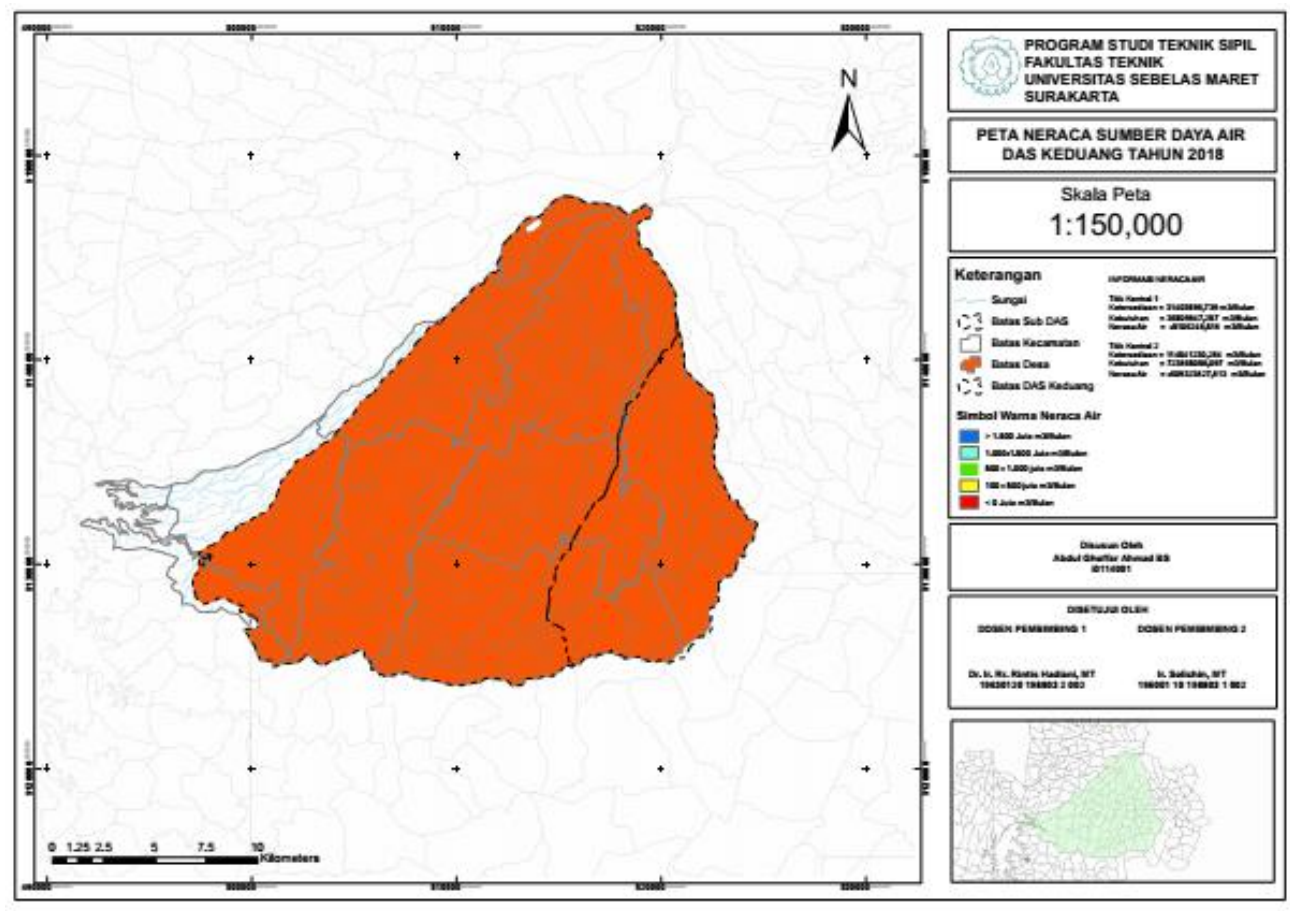

Gambar 2. Peta Neraca Sumber Daya Air Tahun 2017

\section{SIMPULAN}

Dari Penelitian yang telah dilakukan, diperoleh kesimpulan :

1. Neraca Air pada tahun 2017 dapat disimpulkan sebagai berikut :

a. Pada sub DAS titik Kontrol 1 terjadi surplus Air pada bulan Januari, Februari, dan April. Surplus terbesar terdapat pada Bulan Februari sebesar 4,161 x $10^{6} \mathrm{~m}^{3} /$ bulan. Sedangkan pada bulan Maret, Mei sampai Desember terjadi defisit air. Defisit terbesar terjadi pada bulan Nopermber dengan devisit sebesar 6,926 x $10^{6} \mathrm{~m}^{3} /$ bulan.

b. Pada sub DAS titik Kontrol 2 terjadi defisit air disetiap bulannya. Defisit terbesar terjadi pada bulan Nopermber dengan defisit sebesar 239,862 x $10^{6} \mathrm{~m}^{3} /$ bulan.

2. Prediksi Neraca Air pada Tahun 2018 dapat disimpulkan sebagai berikut :

a. Pada sub DAS titik Kontrol 1 terjadi Surplus Air pada bulan Januari, Februari, dan April. Surplus terbesar terdapat pada Bulan Februari sebesar 5,838 x $10^{6} \mathrm{~m}^{3} /$ bulan. Sedangkan pada bulan Maret, Mei sampai Desember terjadi defisit air. Devisit terbesar terjadi pada bulan Oktober dengan defisit sebesar $6,157 \times 10^{6} \mathrm{~m}^{3} /$ bulan.

b. Pada sub DAS titik Kontrol 2 terjadi surplus Air pada bulan Januari dan Februari, dengan surplus terbesar pada bulan Februari sebesar 7,444 x $10^{6} \mathrm{~m}^{3} /$ bulan. Sedangkan pada bulan Maret-Desember terjadi defisit air. Defisit terbesar terjadi pada bulan Nopermber dengan defisit sebesar 234,838 x $10^{6}$ $\mathrm{m}^{3} /$ bulan.

3. Peta neraca Sumber Daya Air Dapat dilihat pada Lampiran D. Dalam Peta diketahui Neraca Air Tahun 2017 menunjukkan defisit sebesar 656,358 × $10^{6} \mathrm{~m}^{3} /$ tahun dan Prediksi Neraca Air Tahun 2018 menunjukkan defisit sebesar $609,324 \times 10^{6} \mathrm{~m}^{3} /$ tahun

\section{UCAPAN TERIMAKASIH}

Ucapan trimakasih kepada dosenn pembimbing yang telah senantiasa sabar memberikan bimbingan, rekan-rekan Teknik Sipil angkatan 2014 yang senantiasa memberi motivasi dan seluruh pihak-pihak yang telah banyak membantu dalam penelitian ini.

\section{DAFTAR PUSTAKA}

Badan Standarisasi Nasional. 2015. SNI 6728.1-2015 : Penyusunan Neraca Spasial Sumber Daya Alam - Bagian 1 : Sumber Daya Air. Jakarta : Badan Standarisasi Nasional (BSN). 
Badan Standarisasi Nasional. 2004. RSNI T-01-2004 : Tata cara Penghitungan evapotranspirasi tanaman acuan dengan metode Penman-Monteith. Jakarta : badan Standarisasi Nasion/al (BSN).

Badan Standarisasi Nasional. 2015. SNI 6738 : 2015 : Perbitungan debit andalan sungai dengan kurva durasi debit. Jakarta : badan Standarisasi Nasion/al (BSN).

Destiana Wahyu, Rintis Hadiani, Suyanto. 2016. Transformasi bujan-debit berdasarkan analisis Tank Model dan GR2M di DAS Dengkleng. E-jurnal Matriks Teknik Sipil, hal 537-543. Surakarta : Universitas Sebelas maret

Novinda Lestari, Nuri Wahyuningsih. 2012. Peramalan Kunjungan Wisata dengan Pendekatan Model SARIMA (Studi Kasus : Kusuma Agrowisata). Jurnal Sains dan Seni, No.1. ISSN : 2301-928X : A29-A33. Surabaya : Institut Teknologi Sepuluh November (ITS)

Vieux Bukhaly TRAORE, dkk. 2014. Calibrating The Rainfall-Runoff Model GR4J And GR2M On The Koulountou River Basin, A Tributary Of The Gambia River. American Journal of Environmental Protection 2014;3(1):36-44. Science Publishing Group. American.

Yosephyna Puspa Setyosari, Rintis Hadiani, Suyanto. 2015. Simulasi bujan-debut di daerah aliran sungai bah bolon dengan metode Mock, Nreca, dan GR2M . E-jurnal Matriks Teknik Sipil. Surakarta : Universitas Sebelas Maret 